\title{
Section News / Nouvelles des sections
}

\section{Nova Scotia}

Forest protection will be the theme of the joint Annual Meeting of the Nova Scotia Forest Technicians Association and the Nova Scotia Section of the Canadian Institute of Forestry on March 11-12 in Truro.

Dr. Max McCormick of the University of Maine will be the keynote speaker. Other speakers at the meeting, which will focus on the use of herbicides and insecticides, include local government and industry foresters and a representative from the Pest Control Products Section of Health and Welfare Canada.

Allan Eddy

\section{Section Champlain}

Le 6 novembre dernier avait lieu au centre-ville de Montréal un dîner-causerie où l'orateur invité fut M. Jean Bérard, secrétaire-trésorier de l'Institut canadien de recherche en génie forestier, mieux connu sous le sigle FERIC. M. Bérard expliqua le rôle joué par FERIC, son organisation et les recherches en cours ou à venir. La trentaine de personnes présentes, principalement des membres de la section, ont très apprécié cette causerie pour son contenu et pour les talents de présentateur de $\mathrm{M}$. Bérard.

De plus, le 25 novembre, une soirée d'information sur les carrières en techniques forestières a eu lieu au Cegep John Abbott. Cette soirée rassembla des techniciens forestiers oeuvrant dans divers secteurs de la foresterie, ainsi que les étudiants en techniques forestières du Cegep. Cette réunion prit la forme d'un panel composé de:

\section{Serge Beaudoin, contremaître de coupe La Cie Jame McLaren Buckingham}

Michel Richer, Technologiste forestier Ministère de l'énergie et des Ressources, St-Jovite

Michel St-Amour, Assistant à la recherche FERIC, Pointe-Claire

Quelques membres de la section étaient présents pour compléter les présentations et aussi répondre aux questions des étudiants. Encore une fois, le tout fut un succès et on ne peut qu'espérer la même participation des membres aux activités de la section.

François Sauvageau

\section{Rocky Moubntain}

The 1981 Autumn meeting of the Rocky Mountain Section was held last fall at the Pine Ridge Forest Nursery. Due to a dramatic outbreak of forest fires attendance was well below what was expected. The theme of the meeting was "tree improvement and forest genetics in Alberta". It began with a tour of the nursery followed by the technical session. Bill
Baker, tree improvement forester for the Alberta Forest Service, was moderator for a panel of seven speakers. Con Dermott, Director of the Reforestation and Reclamation Branch of the Alberta Forest Service, set the stage for the meeting. Mr. Dermott reviewed the provincial government's decision in the early 70's to begin and to promote practising intensive forest management in Alberta. The decision was not the result of anticipated wood shortages as is the case in much of Canada rather it was an upshot from the realization that intensive forest management is the means for expanding and improving the province's wood supply. This is particularly true in light of the gradual reduction in the size of Alberta's forest land base. He went on to describe the actions being taken by the Alberta Forest Service to increase inputs into forest regeneration in order to improve the yields and quality of future forests. The Genetics and Tree Improvement Program is just one of the moves in the intensification of forest management practices. Mr. Dermott concluded his talk by explaining that at present a committee of industry and government foresters are reviewing intensive management practices from a policy and an operational point of view in order to develop recommendations regarding silvicultural practices, policy and regulation adjustments and research requirements. Following Mr. Dermott's speech, Dennis Young, research manager for Procter \& Gamble Cellulose Ltd., outlined the activities of the Forest Management Agreement Companies - Alberta Forest Service Cooperative Tree Improvement Program. The objectives of the joint program are to develop improved seed for reforestation projects in Alberta, to promote cooperation in the field of forest genetics and tree improvement as to benefit all of Alberta's forest industry and to develop the information base for the sound implementation and interpretation of forest management guidelines. Mr. Young elaborated on the justifications for forming a cooperative and its existing organizational set-up. Brian Adams, management forester for Canadian Forest Products Ltd., proceeded to describe the criteria and procedures used by the cooperative in assembling a base population of breeding material through plus tree selection and the progress made to date. Daryl D'Amico, management forester for Blue Ridge Lumber (1981) Ltd., discussed the steps being taken to determine the genetic merit of the selected breeding material through progeny testing and the procedures followed to develop progeny test sites. The first day's activities were concluded with a banquet highlighted by a lively speech by Hank Spencer of Spencer-Lemaire Industries Ltd. dealing with container practices. The following day the technical session continued with three speeches on forest genetics and tree improvement research. The first speaker, Janet Schilf, tree improvement research forester for the Alberta Forest Service, discussed the Forest Service's research program. She pointed out that realized tree improvement is ultimately the product of research. Dr. Jerry Klein of the Canadian Forestry Service, gave a comprehensive talk on the jack pine tree improvement program for the Prairie Provinces of which he is coordinator. Dr. Klein's speech was followed by Bill Cheliak and John King, doctorate students at the University of Alberta. They discussed the potentially powerful role isoenzyme studies could play in forest genetic research and tree improvement and the work they are doing for theses. The meeting ended with a tour of the Alberta Forest Service Genetics and Tree Improvement Facility and field trials at Pine Ridge Forest Nursery. Before I conclude my report on the Fall meeting I would like to share with all foresters reading this Forestry Chronicle a few words that Daryl D'Amico said at the meeting. They are "Remember the first forest was a gift of nature. The next one is up to us." It is up to all of us, and not just foresters, to 
ensure the existence and quality of our forested land base now and in the future.

The Rocky Mountain Section is pleased to announce the creation of a Section newsletter to be entitled "The Canadian Institute of Forestry Rocky Mountain Section Notes". The first edition is expectd in March.

J. Schilf

\section{Okanagan}

Forestry talks to school, liaison with Members of Parliament, and the revision of our section bylaws, highlight some of the activities of this section. Hugh Goodman, management forester for Weldwood of Canada Ltd., Quesnel, addressed the section on intensive forestry management in New Zealand and A.B. Robinson reported on the National $\mathrm{CIF}$ meeting.

At the November Section meeting, Dr. Wayne Johnstone, $\mathrm{BC}$ Ministry of Forests, discussed pre-commercial thinning and spacing in lodgepole pine stands. Wayne recommended that stands with less than 8000 stems/ha should be given a low priority for thinning and that a post-treatment density of about 2000 stems/ha is desirable in young stands. Wayne also recommended that stand tending operations should not be undertaken in areas with a high incidence of root rot.

Several members of the section council joined with the Association of BC Professional Foresters Regional Public Affairs Committee in a "Meet the Media" seminar. The discussion on how to prepare for and meet the media was led by Betty Amos (BC Ministry of Forests).

The feasibility of the establishment of demonstration forests to coincide with the 75th Anniversary of the CIF is currently being investigated.

Paul Birzins

\section{Vancouver Section}

The Vancouver Section's activities have centered around the monthly dinner meetings. On November 10,1981 about 100 members and guests gathered to listen to the program which was entitled "Forest Policy from Different Perspectives'. The effect of British Columbia's recent (1979) Forest legislation was the topic. Mr. Bruce Devitt, (Chief Forester, Pacific Forest Products), the Moderator, introduced the topic and the speakers. He stated that Canada was in the transition from utilizing natural forests to utilizing managed forests. This change will require changes in tenures, stumpage, and industrial structure. Mr. Mike Apsey (Deputy Minister, Ministry of Forests) spoke as a representative of the government. The forest legislation provided the base upon which policy could be enacted. Policy formation requires tradeoffs and compromise, and it must be well planned and systematized to fulfill the objectives of the legislation. The Timber Supply Area identification, yield analysis and rationalization of types of tenures, along with the selection of an apportionment plan (the Vancouver Region plans are to be released on January 25 ) will provide the key steps to the rollover of existing tenures. Mr. Tony Shebbeare (Vice President, Forest and Environment, COFI) spoke as the industry representative. He emphasized that the Acts and the policy originating from them must be viewed only as guidelines, designed and implemented with common sense and experience, which must be conducive to field forestry. The Resource Analysis which must be tabled in the Legislature every five years is important as it forces forestry into public view. Many difficult and complex issues remain to be resolved, in particular, the implementation of the Section 52 incentives, funding problems, and the conflicts with other incompatible legislation (Fisheries Act). Mr. Jack Toovey (President, Association of BC Professional Foresters) spoke as the representative of Professional Foresters. The key to effective forest management is a secure future forest land base. Professional foresters must expand and diversify their expertise into other forest land use areas so that they can maintain their key role as shapers and developers of policy.

The December 8 meeting, attended by about 75 members, was entitled "A Look at Our Managed Forests". Mr. Bill Backman was the Moderator, Mr. Bernie Waatainen (Thinning Forester for MacMillan Bloedel) reviewed M.B.'s program of managing second and subsequent rotation forests through commercial thinnings. Commercial thinnings must be treated as a silvicultural process which will produce usable low value wood at a relatively high cost. The objectives (and benefit) of the thinning regimes must be defined early in the process and centre on two basic choices; maximizing fiber recovery or producing larger, higher quality logs for the final harvest. Mr. Cliff Bowering (Operations Manager of Crown Zellerbach's Coast Wood Products) discussed the problems encountered in processing second growth timber. Second growth timber is smaller and more dense. The mills must handle more pieces and will produce a lower value product (less clears and timbers).

The January 11, 1982 meeting was held jointly with the Association of British Columbia Professional Foresters to mark the 25th Anniversary of the arrival in British Columbia of the students and staff of the Faculty of Forest Engineering of the University of Sopron, Hungary. The dinner (attended by over 250 people) was a spectacular tribute to the Hungarian staff and students who emigrated to Canada following the Soviet suppression of the Hungarian Revolution in October 1956. One hundred and forty-two have graduated from University, twenty-two with Masters degrees, and eight with Doctorate degrees. The dinner was followed by short speeches by-members of the Sopron group, the Canadians who helped them settle, and ended with an exchange of commemorative plaques between the Association of BC Professional Foresters and the Sopron group.

Thomas J. Lundgren, RPF

\section{EDWARD FELLOWS \\ FORESTRY \& FOREST PRODUCTS CONSULTANT \\ P.o. Box 354, 404 Queen St., MEMBER: FREDERICTON, N. B. Registered Professional Forester (N. B.) Canadion Institute of Forestry Forest Products Research Society, Etc.

